\title{
Cost-Effectiveness of Depressive Episode Pharmacological Treatment
}

\author{
Mihajlo B. Jakovljević ${ }^{1}$, Yamada Tetsuji², Chen Chia Ching ${ }^{3}$,
} Dejan S. Stevanović ${ }^{4}$, Mirjana R. Jovanović 5 , Katarina D. Nikić Djuričić ${ }^{5}$, Nemanja K. Rančić $c^{6}$, Dejana M. Savić ${ }^{7}$, Nenad M. Biorac ${ }^{8}$, Goran S. Mihajlovićs , Slobodan M. Janković ${ }^{1}$

\author{
${ }^{1}$ Department of Pharmacology, The Faculty of Medical Sciences, University of Kragujevac, \\ Serbia \\ ${ }^{2}$ Department of Economics, Center for Children and Childhood Studies, Rutgers University, \\ the State University of New Jersey, U.S.A. \\ ${ }^{3}$ Department of Epidemiology \& Community Health, School of Health Sciences \& Practice, \\ New York Medical College, U.S.A. \\ ${ }^{4}$ Clinic for Neurology and Psychiatry for Children and Youth, Clinical Center of Serbia, \\ Belgrade, Serbia \\ ${ }^{5}$ Psychiatric Clinic, University Clinical Center Kragujevac, Serbia \\ ${ }^{6}$ Centre for Clinical Pharmacology, Medical Faculty, Military Medical Academy University of \\ Defence, Belgrade Serbia \\ ${ }^{7}$ Faculty of Medical Sciences University of Kragujevac, Serbia \\ ${ }^{8}$ Primary Care Facility Svilajnac, Serbia
}

\section{SUMMARY}

Background and Objectives There is a paucity of published cost-effectiveness studies of alternative scenarios in depressive episode acute medical care in Eastern European populations.

Methods Prospective cost-effectiveness analysis was conducted on 65 depressive patients in a large university clinic [May 2010-February 2012]. Patient visits to attending psychiatrists were scheduled at baseline, 3rd and 8th week. HDRS-17 was deployed to assess clinical efficiency and Q-LES-Q-SF scale for life quality assessment. Resource use and costs were evidenced from the Clinic's electronic registry of discharge invoices [national currency $1 € \approx 115.85$ CSD]. Societal perspective and time horizon of 14 weeks were adopted.

Results No statistically significant difference in HDRS scores before and after introducing treatment $[x 2=4.339 ; p=0.362]$. QALY value increased by the following: 11.77 of the SSRI, 8.93 of the SNRI, and 12.54 of the heterocyclic antidepressant group. Mean ICERs were: SSRI to SNRI [-44,148 CSD/QALY]; SNRI to Heterocyclics [-45,716 CSD/QALY]; Heterocyclics to SSRI [-51,501 CSD/QALY]. Therapeutic response in increment free days: 28.69 days gained SSRI, 21.78 days SNRI, 30.59 days in heterocyclics. Incremental cost per additional depression free day gained was for: SSRI 346.38 CSD per day, SNRI 327.74 CSD, and heterocyclics 201.54 CSD. 
Conclusions This trial evidence elucidates that the heterocyclic antidepressants provide highest "value for money" in QALYs for the depressive episode treatment. According to Incremental cost-effectiveness ratio calculations, heterocyclic antidepressant proved superior to other two options. Cost-effectiveness evaluations have heavier impact to clinical decision making with regards to major depressive disorder treatment in the absence of clear clinical superiority of any major pharmacological protocol.

Keywords: depressive episode; cost-evaluation and assessment; SSRI; SNRI; Heterocyclic antidepressants

\section{INTRODUCTION}

Major depressive disorder [MDD] belongs to the chronic mental illnesses with the most significant budget impact worldwide [1]. This is the case both due to demanding medical care and far reaching consequences of decreased working ability and premature mortality [2]. Antidepressants [ADs] are considered to be the most frequently used intervention for mood disorders treatment. Accumulated evidence from systematic reviews and meta-analyses has shown that different pharmacological ADs do not exhibit substantial efficacy differentials among majority of patients [3]. First choice of ADs in treating individual patients is largely determined by the clinical features of the depressive episode, patient preferences, and the affordability of specific drugs [4].

There is a large volume of published evidence on cost-effectiveness [5] and costutility of different depression treatment strategies [6]. Most of these assessments were recently compared in a well designed systematic review [7]. Multiple treatment meta-analysis reported that one of the selective serotonin reuptake inhibitors [SSRIs] escitalopram, was the most cost-effective therapy of depression in primary care settings among the other antidepressants tested [citalopram, duloxetine, fluoxetine, fluvoxamine mirtazapine, paroxetine, reboxetine, sertraline and venlafaxine] [8]. Although very useful indeed, the international debate was raised whether the incremental cost-effectiveness ratio [ICER] [9] and cost per quality-adjusted life year [QALY] approaches are providing enough back up for informed decision making [10]. Nevertheless cost-effectiveness study remains the best methodological framework presenting broad horizon and sufficient detail to policy makers [11]. However, it is important to take into account not only the drug itself, but also whether it is original or a generic copy [12]. Balkan markets have been flooded with generic drugs manu- factured mostly by Indian companies over the course of years, substantially decreasing drug acquisition costs in the cost-effectiveness equation. However additional effort to assess actual contribution of this effect was rather out of scope and budget of current study. Aims of this research were to fill the literature gap and compare costs and clinical outcomes of pharmacological treatment protocols in major depressive disorder. This has been done using a prospective randomized clinical study in an upper-middle income Eastern European setting [13].

\section{SUBJECTS AND METHODS}

\section{Setting}

The trial was conducted at a psychiatry clinic within the 1,300 bed, large university hospital of Kragujevac in Serbia. The hospital is the only tertiary facility in the region, providing approximately 50,000 hospital admissions and 400,000 outpatient examinations per year. The psychiatry clinic has a 61 bed capacity and 30 admission places in the intensive outpatient facility. Among designs considered were longitudinal cohort studies, retrospective studies and case series. The most proper study design to address research questions was a clinical case series. The previous two methods were eliminated either on grounds of being too demanding in terms or long time horizon and budget needed or lack of relevant clinical data. The one selected won on grounds of providing sufficient insight into costs and outcomes while offering best feasibility to be conducted alongside routine clinical practice and in real world setting. Participating researchers/attending physicians were not blinded for the subgroup allocation process. Patient sub-populations were compared among themselves without a placebo controlled group. Such a decision has been made due to the serious ethical issue of placebo administration in severe depression due to increased risk of suicidal tendency oc- 
currence [14]. Study duration extended from May 2010 to February 2012.

\section{Entry and selection criteria}

There were in total 1,164 patients suffering from F.32 [Major depressive disorder-single episode] by the International Classification of Diseases 10 revision-ICD-10 and 861 registered cases of F.33 [ICD-10-Major depressive disorder-recurrent] in 2010. In 2011, the total patients were 1,496 by F.32 and 768 by F.33. Outpatients were 1,777 by F.32 and 844 by F.33, who were examined at the regional psychiatry clinic during the period of 2010-2012. Out of this available prevalent pool of patients, our 65 cases were randomly selected out of those fulfilling inclusion and exclusion criteria. The patient recruitment was based on either experience of a first depressive episode, or clinical relapse which were previously diagnosed with chronic recurrent depression. Both conditions were demanding pharmacological treatment introduction.

Principles of good clinical practice [GCP] were obeyed and patients signed an informed consent to participate in the trial. Inclusion criteria were confirmed diagnosis of major depressive disorder-single episode or major depressive disorder by the ICD- 10 . The prescription of the selected pharmacology treatment protocols was based on attending psychiatrist's independent clinical assessment. Exclusion criteria were age less than 18, pregnancy, breast feeding, presence of other major mental illness, and presence of cognitive impairment or significant physical comorbidities.

Duration of clinical follow up per patient was eight weeks from the inclusion time point. Three cross sections were done: A zero week inclusion time point as the baseline after three weeks and eight weeks from the inclusion point. Resource use patterns and costs were evidenced for up to 14 weeks from study entry. Chronological cross-sections were planned in accordance with expected occurrence of clinically significant drug effectiveness [15]. There were in total 65 patients included in the trial. Five patients were lost to follow up either due to change of contact details, poor study compliance, missing physician visits, and lack of relevant data. Ultimately 60 patients providing insight into all of the necessary data were considered in further analysis.

\section{Intervention}

Pharmacology treatment protocols were prescribed according to evidence-based clinical practice guidelines [16]. Each patient had one major antidepressant agent administered in a full dosing regimen. These cases were treated by either one of the following medicines: escitalopram, venlafaxine, sertraline, fluoxetine, paroxetine, maprotiline, bupropion, trazodone or mirtazapine. Based on pharmacological properties of the main antidepressant drug, selected patients belonged to either the selective serotonin reuptake inhibitors [SSRIs] group, serotonin-norepinephrine reuptake inhibitors [SNRIs] or Heterocyclic antidepressant group for the final analysis. The vast majority of prescribed and consumed antidepressants and add-on drugs were original brand name preparations with limited generic medicines presence.

\section{Outcomes}

Patient-reported outcomes are widely regarded as a particular stronghold of treatment success estimation in mood disorder [17]. An attending physician participating in our study was focused on psychometric assessment and two different patient-centered qualities of life [QOL] questionnaires. Major outcomes were clinical improvement-response to treatment assessed by the Hamilton Depression Rating Scale [HDRS] [18] and life quality assessed by the Quality of Life Enjoyment and Satisfaction Questionnaire [Q-LES-Q-SF] [19]. These instruments used were standardized and validated in Serbian language and exploited in a previously published study [20].

Hamilton Depression Rating Scale [HDRS] was widely accepted as a "gold standard" questionnaire for clinical ratings of depressive mood disorder. The original 1960 scale consists of 17 items. Each item on the questionnaire is scored on a 3 or 5 point scale, depending on the item, and the total score is compared to the corresponding descriptor. Normal score range is 0-7 and indicates absence of major mood disorders. Scores $\geq 20$ or higher indicate moderate or severe depression [21].

The Q-LES-Q-SF is a-16-item selfreported questionnaire. The scale is created to assess overall satisfaction with physical health, mood, job duties, household and leisure time activities, social and family relationships, daily functioning, sexual life, economic status, over- 
all well-being and medications. Responses are scored on a 5-point Likert type scale, where higher scores indicate better enjoyment and satisfaction with life [possible range 14-70]. Fourteen summated items create the total QLES-Q-SF score [19].

An unit indicator to present success rate of a treatment option was calculated as a day free from depressive symptoms [DFD] [22]. The cost per quality adjusted life year [QALY] was a proxy of a cost-utility indicator [23]. In order to compare alternative treatment strategies among subgroups, this study evaluated medical care costs per cured depressive episode. Cost-effectiveness measure was assessed by cost/DFD unit itself.

The number of DFDs was calculated according to the following principles: if a patient's HDRS score was $\geq 22$, it was assumed that patient had no DFD; if HDRS was $\leq 7$, it was assumed to have a full DFD; if $22 \geq$ HDRS $\geq 7$ then DFD was weighted in a proportionate manner. The summary amount of DFD over eight weeks interval was obtained by adding the calculated number of DFDs for the baseline of 8 weeks HDRS score, dividing by two, and multiplying by the 56-day interval between study entry and final assessment. Each whole DFD gained was multiplied by a 0.41 ratio for one additional quality adjusted day. In this way, the value of QALY gains was obtained [24-27].

\section{Resource Utilization}

This study adopted broad societal perspective. Therefore, most direct medical costs and indirect productivity related costs were taken into account. The expenses of hospital inpatients and outpatients were extracted from electronic registry of discharge invoices provided by the institutional framework of the university clinic. The official price list of Republican Health Insurance Fund of Serbia at the time of service provision was adopted. The expenses of outof-pocket drug acquisitions were evidencebased by a recommended treatment regimen at hospital discharge with patient compliance assessment. Average market prices at the time of service provision were taken into account. Indirect productivity loss attributed to patient care, absenteeism, working days lost, and premature working disability were calculated based on Grossman's human capital approach [28]. Adopted time horizon was 14 weeks, which were regarded sufficient to ob- serve most of the outcomes and resource use attributable to depressive episode and its treatment. Discounting was neglected due to rather short-time horizon not allowing for substantial currency value distortion.

\section{Data Analytic Procedures}

For continuous variables, mean $[\mathrm{M}]$ and standard deviation [SD] were calculated. Fisher's or $\chi 2$ test were applied to assess differences for categorical variables. Student t-test or MannWhitney U-tests were used to assess differences for continuous variables, depending on the distribution of data. In order to analyze statistical significance of continuous variables across three chronological cross-sections within the same group of patients, unifactorial analysis of variance [ANOVA] for parameter data, and the Friedman Test for nonparameter data were employed. All p-values of 0.05 or below were considered statistically significant. The accepted level of significance for the probability of error of the first order is 0.05 . To process the data we will use the statistical package "SPSS" version 19.

\section{RESULTS}

All patients were between 23 and 76 years old as visible in Table 1 . There were 33 females or about $55 \%$ of total sample but this sex difference was not statistically significant $[\chi 2=0.60$; $\mathrm{p}=0.439]$ Nevertheless, age stratified analysis showed that there was significant domination of 6th life decade patients [24 patients, app. $40 \%]$ in total sample $[\chi 2=30.878 ; \mathrm{p}=0.000]$ compared to other age layers. There were no statistically significant sex differences among patient groups $[\chi 2=1.505 ; \mathrm{p}=0.471]$. Age stratified analysis has proven that most patients [ 24 out of total sample] were in their 6th life decade [app. 40\%], which is statistically significant compared to other age groups.

The study was conducted in order to address an eternal efficacy issue: how much resource allocation increase provides better clinical outcomes, which is shown in Table 2. Our results proved SNRI in a local setting present the most expensive treatment option [242,344.74 CSD], which is statistically significant $[\mathrm{C} 2=10.255 ; \mathrm{p}=0.006]$. Additionally, total direct medical costs also exhibited a statistically significant difference between three treatment options $[\mathrm{C} 2=11.248 ; \mathrm{p}=0.004]$ with SNRI contributing by the highest value-based 


\begin{tabular}{lrrrrl}
\multicolumn{1}{l}{ SSRI } & \multicolumn{3}{l}{ Heterocyclics } \\
Total $N^{\circ}(\%)$ & $34(56.67 \%)$ & $14(23.33 \%)$ & $12(20.00 \%)$ & $x 2=15.342 ; p=0.000^{*}$ \\
Male & $15(44.12 \%)$ & $8(57.14 \%)$ & $4(33.33 \%)$ & $x 2=0.60 ; p=0.439$ \\
Female & $19(55.88 \%)$ & $6(42.86 \%)$ & $8(66.67 \%)$ & \\
Male age $(x \pm$ SD) & $53.33( \pm 11.45)$ & $47.63( \pm 17.39)$ & $46.50( \pm 7.33)$ & $t=0.203 ; p=0.84$ \\
Female age $(x \pm$ SD) & $49.33( \pm 11.89)$ & $51.50( \pm 7.37)$ & $55.38( \pm 8.79)$ & \\
F.32. & $16(47.06 \%)$ & $4(28.57 \%)$ & $5(41.67 \%)$ & $x 2=1.39 ; p=0.499$ \\
F.33. & $18(52.94 \%)$ & $10(71.43 \%)$ & $7(58.33 \%)$ & \\
& $\mathrm{U}=110.5 ; \mathrm{p}=0.375$ & $\mathrm{U}=18.5 ; \mathrm{p}=0.475$ & $\mathrm{U}=7.0 ; \mathrm{p}=0.126$ &
\end{tabular}

share. The total direct and indirect costs of acute depressive episodes for 60 patients was $8,297,321.26$ CSD [an average value per patient was $138,288.69$ CSD]. SNRI treatment with its consequences proved to be the most expensive one and this intergroup difference was significant $[\mathrm{C} 2=10.255 ; \mathrm{p}=0.006]$. Total direct medical costs were significantly higher among SNRI treated patients $[\mathrm{C} 2=11.248$; $\mathrm{p}=0.004]$.

Average indirect productivity loss related costs were also substantially higher within the SNRI group [C2=9.995; $\mathrm{p}=0.007]$. Although the cost of primary medical care is also highest within SNRI [10,029.08 CSD], this difference was not significant. Unlike these ones, costs of hospital care are highest within the
SSRI group, although this difference was not significant either. Total drug acquisition costs were insignificantly higher within SSRI group compared to another two.

Duration of job absenteeism among patients and/or the family member in charge within SNRI group [49.50 days] in Table 3. Within the same group, total duration of hospital admission was significantly longer. Total number of hospital admissions during follow group. An average patient was admitted 2.44 times. Total frequency of outpatient visits was slightly higher in the SSRI group compared to others but not significantly. An average patient in the total sample visited the outpatient clinic of their home care was significantly longer up was insignificantly higher within the SNRI

\begin{tabular}{|c|c|c|c|c|}
\hline & SSRIs & SNRIs & Heterocyclics & Total Sample \\
\hline \multicolumn{5}{|l|}{ Primary Care Costs } \\
\hline \multirow[t]{2}{*}{ M (mean) per patient } & $6,731.20$ & $10,029.08$ & $6,596.07$ & $7,636.77$ \\
\hline & & $C^{2}=1,796 ; p=0,407$ & & \\
\hline \multicolumn{5}{|l|}{ Hospital Inpatient Costs } \\
\hline \multirow[t]{2}{*}{$M$ (mean) per patient } & $121,195.56$ & $100,886.52$ & $43,437.17$ & $94,928.32$ \\
\hline & & $C^{2}=5,812 ; p=0,055$ & & \\
\hline \multicolumn{5}{|c|}{ Hospital Outpatient Costs } \\
\hline \multirow[t]{2}{*}{ M (mean) per patient } & $174,722.97$ & $54,108.68$ & $45,836.65$ & $92,934.77$ \\
\hline & & $C^{2}=3,524 ; p=0,172$ & & \\
\hline \multicolumn{5}{|c|}{ Pharmaceuticals - Drug Acquisition Costs } \\
\hline \multirow[t]{2}{*}{$M$ (mean) per patient } & $17,294.28$ & $16,236.89$ & $10,423.84$ & $15,673.47$ \\
\hline & & $C^{2}=0,435 ; p=0,805$ & & \\
\hline \multicolumn{5}{|l|}{ Direct Medical Costs } \\
\hline \multirow[t]{2}{*}{$M$ (mean) per patient } & $7,1533,86$ & $123,618,49$ & $44,528,97$ & $78,285,96$ \\
\hline & & $C^{2}=11,248 ; p=0,004$ & & \\
\hline \multicolumn{5}{|c|}{ Indirect - Lost Productivity Costs } \\
\hline \multirow[t]{2}{*}{ M (mean)per patient } & $45,430.60$ & $118,726.25$ & $32,779.64$ & $60,002.73$ \\
\hline & & $C^{2}=9,995 ; p=0,007^{*}$ & & \\
\hline \multicolumn{5}{|l|}{ Total Costs } \\
\hline \multirow[t]{2}{*}{$M$ (mean) per patient } & $116,964.46$ & $242,344.74$ & $77,308.60$ & $138,288.69$ \\
\hline & & $C^{2}=10,255 ; p=0,006^{*}$ & & \\
\hline
\end{tabular}


Table 3. Resource use across treatment groups

* Unifactorial analysis of variance (ANOVA) for parameter data and Friedman Test for nonparameter data were employed.

All $p$-values of 0.05 or below were considered statistically significant.
Table 4. HDRS-17 and Q-LESQ-SF total scores across time points per patient values

* Unifactorial analysis of variance (ANOVA) for parameter data and Friedman Test for nonparameter data were employed.

All p-values of 0.05 or below were considered statistically significant.

\begin{tabular}{lcccc} 
& \multicolumn{1}{c}{ SSRI } & SNRI & Heterocyclics & Total Sample \\
\hline Duration of job absenteeism *(days) & & & \\
$M$ M (mean) per patient & 18.94 & 49.50 & 13.67 & 25.02 \\
& & $C^{2}=9,995 ; p=0,007^{*}$ & &
\end{tabular}

Total duration of hospital admissions *(days)

$\begin{array}{ccccc}M \text { (mean) per patient } & 46.45 & 67.33 & 19.29 & 46.37 \\ & C^{2}=7,251 ; p=0,027^{*} & & \end{array}$

Number of hospital admissions

$M$ (mean) per patient

2.27

3.44

1.43

2.44

$C^{2}=3,920 ; p=0,141$

Number of outpatient visits to the attending psychiatrist

$\begin{array}{lcccc}M \text { (mean) per patient } & 2.50 & 1.00 & 1.00 & 1.50\end{array}$

approximately 1.5 times during observation period.

In Table 4 , an average duration of depressive episode intensive treatment was 50.97 days. Clear cut evidence on gradual reduction of HDRS-17 score from point zero toward the last 8 th week physician visit was observed in the total sample. These differences turned out to be statistically significant. Another relevant trend was decrease of percentage of patients with most severe clinical forms of depression and increasing number of patients entering reemission stage. The 14 -week long time horizon we selected confirmed that clinical improvement mostly happens in an acute stage of a depressive episode lasting 6-8 weeks, conditional to the appropriate drug and dosing regimen choice. There were no statistically significant differences in the frequency of satisfactory treatment outcomes among groups $[\chi 2=4.339 ; \mathrm{p}=0.362]$. Quality of life measure- ments provided by Q-LES-Q-SF prove signs of straightforward advancement due to therapy and release of symptoms in all three groups from point zero to the 8th week. Differences among average group values of total Q-LESQ-SF scores were statistically significant with the best improvement detected within the heterocyclic group [means rising from 37.50 to 44.83]; [C2=6,255; $\mathrm{p}=0,044]$.

QALY gained values amounted to [11.77] SSRI, [8.93] SNRI and [12.54] for heterocyclic antidepressant group, while for 95 \% confidence interval we get an average cost/ QALY of 9,937.51 CSD for SSRI; 27,138.27 CSD for SNRI, and 6,164.96 CSD among heterocyclic antidepressant group in Table 5. Ultimately the highest QALY gain [12.54]; [C2=1.643; $\mathrm{p}=0.44]$, the best DFD gain [30.59]; [C2=1.885; $\mathrm{p}=0.390]$ and the lowest cost per QALY value [6, 164.96 CSD]; [C2=1.663; $\mathrm{p}=0.435]$ out of alternatives considered in a local clinical set-

\begin{tabular}{|c|c|c|c|c|c|c|}
\hline $\begin{array}{l}\text { Psychometric } \\
\text { Scale }\end{array}$ & $\begin{array}{l}\text { Time } \\
\text { point }\end{array}$ & SSRIs & SNRIs & Heterocyclics & & $\begin{array}{c}\text { Total } \\
\text { Population }\end{array}$ \\
\hline \multirow{4}{*}{$\begin{array}{c}\text { HDRS-17 } \\
(M \pm S D) \\
\text { per patient }\end{array}$} & Baseline & $17.35 \pm 7.67$ & $22.43 \pm 8.17$ & $17.58 \pm 9.50$ & $\begin{array}{c}C^{2}=3,937 \\
p=0,14\end{array}$ & $18,58 \pm 8,31$ \\
\hline & $3^{\text {rd }}$ week & $15.21 \pm 7.96$ & $14.50 \pm 8.50$ & $15.33 \pm 8.40$ & $\begin{array}{c}C^{2}=0,337 \\
p=0,845\end{array}$ & $15,07 \pm 8,04$ \\
\hline & $8^{\text {th }}$ week & $13.32 \pm 8.73$ & $17.43 \pm 10.56$ & $12.17 \pm 7.79$ & $\begin{array}{c}C^{2}=2,184 \\
p=0,336\end{array}$ & $14,05 \pm 9,07$ \\
\hline & & $\begin{aligned} C^{2} & =7,860 \\
p & =0,02^{*}\end{aligned}$ & $\begin{array}{c}C^{2}=12,259 \\
p=0,02^{*}\end{array}$ & $\begin{array}{c}C^{2}=4,176 ; \\
p=0,125\end{array}$ & & $\begin{array}{l}F=11,474 \\
p=0,000^{*}\end{array}$ \\
\hline \multirow{4}{*}{$\begin{array}{c}\text { Q-LES-Q-SF } \\
(M \pm S D) \\
\text { per patient }\end{array}$} & Baseline & $36.74 \pm 10.42$ & $33.29 \pm 10.11$ & $37.50 \pm 9.47$ & $\begin{array}{c}C 2=1,680 \\
p=0,432\end{array}$ & $36,08 \pm 10,12$ \\
\hline & $3^{\text {rd }}$ week & $40.06 \pm 12.26$ & $39.57 \pm 11.55$ & $41.67 \pm 13.09$ & $\begin{array}{c}C 2=0,191 \\
p=0,909\end{array}$ & $40,27 \pm 12,08$ \\
\hline & $8^{\text {th }}$ week & $42.76 \pm 12.59$ & $37.86 \pm 10.78$ & $44.83 \pm 10.56$ & $\begin{array}{c}C 2=2,445 \\
p=0,294\end{array}$ & $42,03 \pm 11,88$ \\
\hline & & $\begin{array}{c}C^{2}=17,922 ; \\
p=0,000^{*}\end{array}$ & $\begin{array}{c}C^{2}=10,302 \\
p=0,006^{*}\end{array}$ & $\begin{array}{l}C^{2}=6,255 ; \\
p=0,044^{*}\end{array}$ & & $\begin{array}{l}F=21,214 \\
p=0,000^{*}\end{array}$ \\
\hline
\end{tabular}




\begin{tabular}{|c|c|c|c|c|c|}
\hline & $\begin{array}{l}\text { DFD gains } \\
\qquad(x \pm S D)\end{array}$ & $\begin{array}{l}\text { QALY gains } \\
\text { per patient } \\
(\mathrm{X} \pm \mathrm{SD})\end{array}$ & $\begin{array}{l}\text { Cost per } \\
\text { QALY (ACER) } \\
\text { (CSD/QALY) }\end{array}$ & $\begin{array}{l}\text { Mean Total } \\
\text { Cost } \\
\text { (CSD) }\end{array}$ & $\begin{array}{c}\text { ICER } \\
\text { (CSD/QALY) }\end{array}$ \\
\hline SSRI & $28.69( \pm 20.23)$ & $11.77( \pm 8.29)$ & $9,937.51$ & $116,964.46$ & $\begin{array}{c}-44,147.98 \\
\text { (SSRI to SNRI) }\end{array}$ \\
\hline SNRI & $21.78( \pm 20.53)$ & $8.93( \pm 8.42)$ & $27,138.27$ & $242,344.74$ & $\begin{array}{c}-45,716.38 \\
\text { (SNRI to Heterocyclics) }\end{array}$ \\
\hline \multirow[t]{2}{*}{ Heterocyclics } & $30.59( \pm 18.44)$ & $12.54( \pm 7.56)$ & $6,164.96$ & $77,308.60$ & $C^{2}=2,184 ; p=0,336$ \\
\hline & $\begin{aligned} C^{2} & =1.885 \\
p & =0.390\end{aligned}$ & $\begin{aligned} C^{2} & =1.643 \\
p & =0.44\end{aligned}$ & $\begin{aligned} C^{2} & =1.663 \\
p & =0.435\end{aligned}$ & $\begin{array}{l}C^{2}=10,255 \\
p=0,006^{*}\end{array}$ & $\begin{array}{c}-51,501.12 \\
\text { (Heterocyclics to SSRI) }\end{array}$ \\
\hline
\end{tabular}

ting, was provided by heterocyclic antidepressants, although these advantages failed to prove statistical significance.

Incremental cost-effectiveness ratios [ICERs] calculated were as follows: $-44,147.98$ [SSRI to SNRI]; -45,716.38 [SNRI to Heterocyclics] and $-51,501.12$ [Heterocyclics to SSRI] as provided in Table 5. Heterocyclic antidepressant proved superior to other two options. Our findings claim that in aSouth-Eastern European upper-middle income setting, marginal provision of one additional QALY in major depression treatment is most affordable among heterocyclic antidepressant treated patients.

\section{DISCUSSION}

Straight forward negative correlation between depressive symptoms of severity and quality of life was reported in different findings [29]. Our results fall within the so called B strategy of depression treatment with cost per QALY $\leq \$ 20,000$ [30 ]. Depression medical care expenditure reported in the literature differs substantially among countries. Few results opposing our results were reporting the most convenient ICER values with venlafaxine [SNRI] of $\$ 2,073$ and highest reemission rates [1]. The local Brazilian trial has also reported lowest costs of care and better treatment outcomes for SNRI classified medicines [31]. Recently published UK data favors venlafaxine treatment in terms of both cost-utility $[1,285 \mathfrak{E}$ per QALY] and $21 £$ cost per DFD compared to alternatives [32]. Unlike previously mentioned findings, a local Columbian study reports lowest cost-effectiveness ratio for more traditional amitriptyline of $\$ 1,274$ and with cost per QALY being even $\$ 31,595$ lower than the venlafaxine reported value [33].

Observing the landscape of published evidence on cost-effectiveness and cost-utility of antidepressants treatment, we may notice that high income clinical settings and few ma- jor emerging ones favor SNRI [venlafaxine] both due to sudden clinical improvement attributed to this medicine and most affordable cost per depression free day achieved. The last criterion is consistent with our findings.

Reported estimates of high SSRI related hospital resource use and costs seem to be consistent with our findings. Among some South American emerging markets, cost per day of hospital treatment [ $\$ 81$ in Columbia and \$293 in Brazil] remains similar to our reported values, but in high income markets of North America it can be 8-15 times more expensive. There is evidence supporting the claim that hospital admission costs amount to almost 43$75 \%$ of total costs and are therefore the leading contributor to the total direct medical costs of depression care [2]. Antidepressant medicine costs differ substantially among markets but usually fall within $2 \%-11 \%$ range [34 ].

Clinical assessment by means of HDRS-17 reported values steadily decreased in all Serbian patients during the follow up period. These differences among group values of HDRS-17 and Q-LES-Q-SF detected during three scheduled visits to the attending psychiatrist proved to be statistically significant. This evidence proves clinical improvement in terms of depression free days and life quality on total sample. Nevertheless, this trial supports widely adopted knowledge on modest efficiency differentials among major antidepressant medicines. The dominant elderly population that has been observed is particularly vulnerable to the depressive mood disorders [35]. Population of elderly has additional difficulties with healthcare access which has been proven in other communities worldwide [36].

Many patients after successful outcomes in psychiatric disease management enter lasting remissions [37] which may reflect to life quality improvement. Real world health economic assessments alongside clinical trials on efficiency offer some significant method-
Table 5. Treatment outcomes: depression free days (DFD) calculated on basis of HDRS-17 score; QALY gains per patient, Mean total cost per patient, cost per QALY values (Average Cost-Effectiveness Ratio -ACER); Incremental Cost-Effectiveness Ratio-ICER

* Unifactorial analysis of variance (ANOVA) for parameter data and Friedman Test for nonparameter data were employed. All p-values of 0.05 or below were considered statistically significant. 
ological advantages compared to modelling approach in terms of microcosting and clinical outcomes assessment [38]. Size of mental disorder related costs of care seems to be just slightly lower in Serbia compared to Central European values $[39,40]$. Structure of costs indicates direct costs are prevailing against indirect cost contribution. This is profoundly different in high income settings which is caused by substantially higher labor wages and therefore higher significance of job absenteeism and lost productivity due to lasting mood disorders [41,42].

\section{Study Limitations}

This study had an uneasy task to address far reaching issues of costs and consequences of pharmacological treatment protocols in major depressive disorders. Although this challenge was processed within widely adopted methodological framework, there were several weaknesses imposing restrictions on study conclusions. Sample size should have been sufficient to test the hypothesis according to some published data, but nevertheless bigger treatment groups would eliminate few study biases arising from sample heterogeneity. Age structure with tendency towards 4 th, 5th and 6th life decade is limiting conclusions to these age groups.

Uncertainty impact was not assessed and sensitivity analysis was avoided due to a rather limited sample size and short time horizon of the study. Treatment response among almost one half of all patients was rather poor and failed to achieve satisfactory mood stabilization. This was probably due to insufficient psychotherapy support during initial weeks of clinical follow up. Opposing to aforementioned weaknesses, there are also two strengths of this trial that make publishing of these data useful for policy makers. This was an in depth case series analysis and one of the pioneering efforts on mental illness cost-effectiveness analysis in a vast Eastern European region. Fulfilling the knowledge gap in this part of middle income Europe might be essential. Local healthcare settings shape cost-effectiveness of certain medical technologies and are profoundly different when compared with the estimates reported for high income mature economies.

\section{CONCLUSIONS}

Within Southeastern European healthcare set- tings heterocyclic antidepressant treatment of major depressive disorder is the least costly option compared with SSRIs and SNRIs. The main reasons for such a favorable position are low drug acquisition costs and shorter hospitalizations with heterocyclic antidepressants. Favoring this group of antidepressants in clinical practice could bring significant savings to health insurance systems in upper-middle income countries of the region. Among undoubtedly successful cost containment strategies was broad introduction of generic alternatives and facilitating their market access and reimbursement from administrative obstacles [43]. Similar health economic studies alongside clinical trials on effectiveness in mental illnesses should be funded more ambitiously in the region on grounds of rising psychiatric morbidity. Such pioneering local efforts of mental illness health economics could help better understand the healthcare market landscape in Eastern Europe and the Balkans.

\section{FINANCIAL AND CONFLICT OF INTEREST DISCLOSURE}

The authors would like to express their gratitude to the Ministry of Education, Science and Technological Development of the Republic of Serbia, Grant No.175014 and to the Faculty of Medical Sciences University of Kragujevac for Junior Research Grant No 17/10 in 2010 out of which this trial was funded.

\section{ETHICAL COMMITTEE APPROVAL}

This study adhered to the ICH-GCP and Declaration of Helsinki principles and was previously approved by Ethical Committee of the University Clinical Center Kragujevac, Serbia decision number 01-3347. Date of decision: 22.04.2010. Informed consent was provided by all patients participating in this study.

\section{REFERENCES}

1. Malone DC. A budget-impact and cost-effectiveness model for second-line treatment of major depression. J Manag Care Pharm 2007; 13 [6 Suppl A]: S8-18.

2. Luppa M, Heinrich S, Angermeyer MC, König HH, Riedel-Heller SG. Cost-of-illness studies of depression: a systematic review. J Affect Disord 2007; 98[1-2]: 29-43.

3. Rocha FL, Fuzikawa C, Riera R, Hara C. Combina- 
tion of antidepressants in the treatment of major depressive disorder: a systematic review and metaanalysis. J Clin Psychopharmacol 2012; 32[2]: 27881.

4. Ristić-Ignjatović D, Hinić D, Jakovljevic M, Fountoulakis K, Siepera M, Rancic N. A ten-year study of depressive symptoms in Serbian medical students. Acta Clin Croat. 2013 Jun;52[2]:157-63.

5. Barrett B, Byford S, Knapp M. Evidence of costeffective treatments for depression: a systematic review. J Affect Disord 2005; 84[1]: 1-13.

6. Pirraglia PA, Rosen AB, Hermann RC, Olchanski NV, Neumann P. Cost-utility analysis studies of depression management: a systematic review. Am J Psychiatry 2004; 161[12]: 2155-62.

7. Zimovetz EA, Wolowacz SE, Classi PM, Birt J. Methodologies used in cost-effectiveness models for evaluating treatments in major depressive disorder: a systematic review. Cost Eff Resour Alloc 2012; 10[1]: 1.

8. Ramsberg J, Asseburg C, Henriksson M. Effectiveness and cost-effectiveness of antidepressants in primary care: a multiple treatment comparison meta-analysis and cost-effectiveness model. PLoS One 2012; 7[8]: e42003.

9. Birch S, Gafni A. Information created to evade reality [ICER]: things we should not look to for answers. Pharmacoeconomics 2006; 24[11]: 1121-31.

10. Soares MO. Is the QALY blind, deaf and dumb to equity? NICE's considerations over equity. Br Med Bull 2012; 101: 17-31.

11. Ramsey $S$, Willke $R$, Briggs $A$, Brown R, Buxton M, Chawla A, Cook J, Glick H,Liljas B, Petitti $D$, Reed S. Good research practices for cost-effectiveness analysis alongside clinical trials: the ISPOR RCT-CEA Task Force report. Value Health. 2005 SepOct;8[5]:521-33.

12. Yu AP, Xie J, Bensimon A, Parikh K, Wu EQ, BenHamadi R, et al. Economic consequence of switching to citalopram after its generic entry for adult patients with major depressive disorder [MDD] treated with escitalopram: a 6-month retrospective study. J Med Econ 2010; 13[4]: 599-609.

13. Hu TW. Perspectives: an international review of the national cost estimates of mental illness, 1990-2003. J Ment Health Policy Econ. 2006 Mar;9[1]:3-13.

14. Storosum JG, van Zwieten BJ, van den Brink W, Gersons BP, Broekmans AW. Suicide risk in placebocontrolled studies of major depression. Am J Psychiatry $2001 ; 158[8]: 1271-5$.

15. Fernandez JL, Montgomery S, Francois C. Evaluation of the cost effectiveness of escitalopram versus venlafaxine XR in major depressive disorder. Pharmacoeconomics 2005; 23[2]: 155-67.

16. Köhler S, Hoffmann S, Unger T, Steinacher B, Fy- drich T. Adherence to guidelines and effectiveness of inpatient treatment for unipolar depression. Int J Psychiatry Clin Pract 2012; 16[2]: 103-12.

17. Savic D, Jakovljevic M. [Estimate of clinical outcomes from the patient perspective is important for clinical decision making]. Racionalna terapija 2012; 4[1]: 47-49. Serbian.

18. Zimmerman M, Martinez JH, Young D, Chelminski I, Dalrymple K. Severity classification on the Hamilton depression rating scale. J Affect Disord 2013; 150[2]: 384-8.

19. Endicott J, Nee J, Harrison W, Blumenthal R. Quality of Life Enjoyment and Satisfaction Questionnaire: a new measure. Psychopharmacol Bull 1993; 29[2]: 321-6.

20. Stevanovic D. Quality of Life Enjoyment and Satisfaction Questionnaire-short form for quality of life assessments in clinical practice: a psychometric study. J Psychiatr Ment Health Nurs 2011; 18[8]: 744-50.

21. Hamilton M. A rating scale for depression. J Neurol Neurosurg Psychiatry 1960; 23: 56-62.

22. Pyne JM, Tripathi S, Williams DK, Fortney J. Depression-free day to utility-weighted score: is it valid? Med Care 2007; 45[4]: 357-62.

23. Jonkers CC, Lamers F, Evers SM, Bosma H, Van Eijk JT. Cost-utility estimates in depression: does the valuation method matter? J Ment Health Policy Econ 2010; 13[4]: 189-97.

24. Lave JR, Frank RG, Schulberg HC, Kamlet MS. Cost-effectiveness of treatments for major depression in primary care practice. Arch Gen Psychiatry 1998; 55[7]: 645-51.

25. van Steenbergen-Weijenburg KM, van der FeltzCornelis CM, Horn EK, van Marwijk HW, Beekman AT, Rutten FF, Hakkaart-van Roijen L. Cost-effectiveness of collaborative care for the treatment of major depressive disorder in primary care. A systematic review. BMC Health Serv Res. 2010 Jan 19;10:19.

26. Watkins KE, Cuellar AE, Hepner KA, Hunter SB, Paddock SM, Ewing BA, de la Cruz E. The cost-effectiveness of depression treatment for co-occurring disorders: a clinical trial. J Subst Abuse Treat. 2014 Feb;46[2]:128-33.

27. Shimodera S, Furukawa TA, Mino Y, Shimazu K, Nishida A, Inoue S. Cost-effectiveness of family psychoeducation to prevent relapse in major depression: results from a randomized controlled trial. BMC Psychiatry. 2012 May 14;12:40.

28. Zweifel P. The Grossman model after 40 years. Eur J Health Econ 2012; 13[6]: 677-82.

29. Stevanovic D, Jancic J, Lakic A. The impact of depression and anxiety disorder symptoms on the health-related quality of life of children and adolescents with epilepsy. Epilepsia 2011; 52[8]: e75-8. 
30. Perlis RH, Patrick A, Smoller JW, Wang PS. When is pharmacogenetic testing for antidepressant response ready for the clinic? A cost-effectiveness analysis based on data from the STAR*D study. Neuropsychopharmacology 2009; 34[10]: 2227-36.

31. Machado M, Iskedjian M, Ruiz I, Einarson TR. The impact of introducing serotoninnoradrenaline reuptake inhibitors in the Brazilian national drug formulary: costeffectivenessand budget-impact analyses. Pharmacoeconomics 2007; 25[11]: 979-90.

32. Lenox-Smith A, Conway P, Knight C. Cost effectiveness of representatives of three classes of antidepressants used in major depression in the UK. Pharmacoeconomics 2004; 22[5]: 311-9.

33. Machado M, Lopera MM , Diaz-Rojas J, Jaramillo LE, Einarson TR, The Universidad Nacional de Colombia Pharmacoeconomics Group. Pharmacoeconomics of antidepressants in moderate-to-severe depressivedisorder in Colombia. Rev Panam Salud Publica 2008; 24[4]: 233-9.

34. Berto P, D'llario D, Ruffo P, Di Virgilio R, Rizzo F. Depression: cost-of-illness studies in the international literature, a review. J Ment Health Policy Econ 2000; 3[1]: 3-10.

35. Fukunaga $R$, Abe $Y$, Nakagawa $Y$, Koyama A, Fujise $N$, Ikeda $M$. Living alone is associated with depression among the elderly in a rural community in Japan. Psychogeriatrics 2012; 12[3]: 179-85.

36. Murata C, Yamada T, Chen C-C, Ojima T, Hirai H, Kondo K. Barriers to Health Care among the Elderly in Japan. Int J Environ Res Public Health 2010; 7[4]: 1330-41.

37. Yamada T, Chen CC, Yamada T. Economic evaluation of relapse prevention for substance users: treatment settings and health care policy. Adv Health Econ Health Serv Res 2005; 16: 431-50.

38. Annemans L, Cleemput I, Simoens S, Arickx $F$, Hulstaert F, Bogaert $M$. The increasing role of health economic evaluations in drug development. Drug Dev. Res 2010; 71[8]: 457-462.

39. Jovanovic M, Jakovljevic M. Inpatient detoxification procedure and facilities: financing considerations from an Eastern European perspective. Alcohol Alcohol 2011; 46[3]: 364-5.

40. Jakovljevic $M$, Riegler A, Jovanovic M, Djordjevic N, Patek K, Lesch O, Walter H. Serbian and Austrian alcohol-dependent patients: a comparison of two samples regarding therapeutically relevant clinical features. Alcohol Alcohol. 2013 JulAug;48[4]:505-8.

41. Jakovljevic MB. Resource allocation strategies in Southeastern European health policy. Eur J Health Econ 2013; 14[2]: 153-9.

42. Jakovljevic, M., Lazic, Z., Verhaeghe, N., Jankovic, S., Gajovic, O., \& Annemans, L. [2013]. Direct medical costs of COPD diagnosis and treatment,
Eastern vs. Western European country: examples of Serbia and Belgium. Farmeconomia, Health Economics and Therapeutic Pathways, 14[4], 161-168.

43. Jakovljevic, M. B., Nakazono, S., \& Ogura, S. [2014]. Contemporary generic market in Japan-key conditions to successful evolution. Expert review of pharmacoeconomics \& outcomes research, [0], 1-14. 


\section{Isplativost farmakološkog lečenja depresije}

Mihajlo B. Jakovljević ${ }^{1}$, Yamada Tetsuji ${ }^{2}$, Chen Chia Ching ${ }^{3}$, Dejan S. Stevanović ${ }^{4}$, Mirjana R. Jovanovićs ${ }^{5}$ Katarina Nikić Djuričić ${ }^{5}$, Nemanja K. Rančić ${ }^{6}$, Dejana Savić ${ }^{7}$, Nenad M. Biorac ${ }^{8}$, Goran Mihajlović ${ }^{5}$, Slobodan M. Janković ${ }^{1}$

\footnotetext{
${ }^{1}$ Katedra za farmakologiju i toksikologiju, Fakultet medicinskih nauka, Univerziteta u Kragujevcu, Srbija ${ }^{2}$ Ekonomski Fakultet, Centar za decu i proučavanje detinjstva, Radžers državni Univerzitet u Njudžersiju , SAD

${ }^{3}$ Odsek za epidemiologiju i javno zdravlje, Fakultet zdravstvenih nauka i prakse, Nju Jork Medicinski Koledž, SAD

${ }^{4}$ Klinika za neurologiju i psihijatriju za decu i omladinu, Klinički Centar Srbije, Beograd, Srbija

${ }^{5}$ Psihijatrijska klinika, Klinički centar Kragujevac, Srbija

${ }^{6}$ Centar za kliničku farmakologiju, Medicinski Fakultet Univerziteta Odbrane, Vojnomedicinska

Akademija, Beograd, Srbija

${ }^{7}$ Fakultet medicinskih nauka Univerziteta u Kragujevcu, Srbija

${ }^{8}$ Dom zdravlja Svilajnac, Srbija
}

\section{KRATAK SADRŽAJ}

UVOD Značajan literaturni deficit na temu isplativosti [troškovne-efektivnosti] farmakoterapije depresivnih epizoda u Istočnoj Evropi nas je podstakao da preduzmemo ovu studiju.

METODE Prospektivna studija isplativosti [troškovne-efektivnosti] je sprovedena na 65 pacijenata sa potvrđenom endogenom depresijom u domaćoj univerzitetskoj klinici [period kliničkog praćenja Maj 2010-Februar 2012]. Pregledi pacijenata kod psihijatra-ordinarijusa su bili zakazani na uvodu u studiju I nakon 3 i 8 nedelja. Hamiltonova skala HDRS-17 je primenjena za procenu kliničke efikasnosti lečenja a skala Q-LES-Q-SF za procenu kvaliteta života pacijenta. Potrošnja resursa I troškovi nege su evidentirani iz elektronskog registra pruženih usluga na osnovu faktura izdatih na otpustu iz dnevne bolnice/bolničkog lečenja. [1 $€ \approx 115.85$ RSD]. Primenjeni su društvena perspektiva I vremenski horizont od 14 nedelja.

REZULTATI Nije bilo statistički značajne razlike u HDRS skoru pre I posle uvedene farmakoterapije [ $x 2=4.339 ; \mathrm{p}=0.362]$. Inkrementalni prirast kvaliteta života [QALY] je iznosio: 11.77 za SSRI grupu, 8.93 za SNRI i 12.54 u grupi lečenoj heterocikličnim antidepresivnim lekovima. Srednja vrednost inkrementalne isplativosti [ICER] je iznosila: SSRI prema SNRI [-44,148 CSD/QALY]; SNRI prema Heterociklicima [-45,716 CSD/ QALY]; Heterociklici prema SSRI [-51,501 CSD/QALY]. Terapijski odgovor u smislu dana bez depresivnih simptoma je iznosio: 28.69 dana za SSRI, 21.78 dana za SNRI, 30.59 dana za heterociklike. Inkrementalni trošak po danu bez depresivnih simptoma je bio: SSRI 346.38 RSD po danu, SNRI 327.74 RSD a heterociklici 201.54 RSD.

ZAKLJUČAK Studija pokazuje da heterociklični antidepresivi pružaju najvišu "vrednost za novac" izraženu u QALY u lečenju depresivne episode u lokalnim uslovima. Prema ICER vrednosti heterociklični antidepresivi pokazuju superiornost u odnosu na preostale dve opcije u lečenju. Procene isplativosti lečenja bi trebale imati veći uticaj na process donošenja kliničke odluke u odsustvu jasne razlike u kliničkoj efikasnosti lečenja depresije izmedju vodećih farmakoterapijskih protokola.

Ključne reči: depresivna epizoda; procena troškova; SSRI; SNRI; Heterociklični antidepresivi

Received: February 1, 2015

Accepted: March 1, 2015 